\title{
Ralph Ellison as Neighbor
}

\section{Hugh Hawkins}

Only slowly did Plainfield realize that it had a distinguished new resident. In a town of three hundred, word eventually got around. The first relevant gossip in the spring of 1967 reported that the Crews place had sold. Amazingly, someone had actually paid that exorbitant asking price of $\$ 35,000$. Then rumor circulated that the purchaser was black, and later that he was a well-known author. I wondered aloud, "Do you suppose we might have Ralph Ellison as a neighbor?" And so it proved to be.

The prospect excited me. I had admired Invisible Man since its appearance in 1952, when in graduate school my apartment mate George Bluestone had helped me understand its genius. I still possessed my battered paperback copy (a Signet Double Volume, 50 cents). As a young instructor at Amherst College, I had included the chapter on Dr. Bledsoe's college in a collection of readings on Booker T. Washington, a new sequence in the college's pioneering "Problems in American Civilization" course. What luck, I thought, to have this illustrious author as a fellow townsman.

Perhaps because he recalled beginning to write Invisible Man during a vacation in rural Vermont, perhaps because his friend the poet Richard Wilbur was thriving in the neighboring town of Cummington, Ralph Ellison and his wife Fanny had chosen a place in this little-known Massachusetts hill town where the eastern edge of the Berkshire highlands joins the southern tip of the 
Green Mountains. At least one hundred fifty years old, the house was located on wooded acres out of sight of other houses, seemingly an ideal location to let a writer to escape the urban distractions of New York. Painted white, it stood out against the brilliant New England fall foliage, but would have disappeared into the winter snows were it not for the low-slung Cape Cod roof. Set well back from the road on land terraced up with a retaining wall of native stone, it could attract the admiration of anyone passing, but the notorious steepness of Lincoln Street meant that few drove or walked that way.

After an economy that drew on light manufacturing by its water-powered mills and later relied on sheep-raising, the town had suffered from the rise of a national, and then an international, market. It was no help that it lay about as far from a railhead as any place in the state. The lack of jobs, the severity of the winters, and the rockiness of the soil had driven many inhabitants west or into the cities. Open fields that older residents could recall had long since returned to forest. Still, the pure air, spectacular fall foliage display, and quaint preservation of an earlier rural culture had for some time attracted a few summer residents.

The Ellisons had purchased a property that, though once sold for unpaid taxes, had been fully restored by its previous owners. The contrast with our experience was striking. The abandoned farm that my partner Walter Richard and I had bought in 1950 offered a dilapidated house and neglected barn, but we found a gifted local carpenter who joined us in restoring them. Given its rundown state, the owner had not driven a hard bargain, warning us not to expect any luck growing a crop on the land. That was far from our intention. As college teachers, we were happy with the prospect of a place for weekend and summer breaks from our regular jobs.

Though much of the charm of the town for us lay in its being virtually unheard of, we both liked the notion of a link to celebrity. Besides, having recently participated in civil rights protests, we welcomed any step toward racial integration. The latest town census recorded no resident in the "Negro" category, though the historical record showed Plainfield as the home of one black participant in Shays's Rebellion of 1787 and one member of the all-black Massachusetts $54^{\text {th }}$ Regiment in the Civil War.

Less than a year after their purchase, fire destroyed the Ellisons' Plainfield house. We had not yet met, but as soon as I heard the news, I wrote him, saying how proud the town was to have him here and expressing the hope that he would not abandon Plainfield. Although he never mentioned this letter, he did later tell me that they had encountered problems with their insurance company. In time, however, the company had found proof that an electrical flaw had been to blame. This was not unlikely in such an old house. In these conversations, he never mentioned any loss of drafts of his writing.

In May, 1969, after hearing his lecture at Amherst, I attended the reception at the college's new black culture center. As I shook hands with Ralph, I mentioned our Plainfield connection but didn't linger for a response. I stood back and watched the adulation of the black students, which seemed undiminished 
by the contrast between his lecture's theme of American inclusiveness and the black separatist ideology then in the ascendency.

Rather than seeking a different summer home, the Ellisons chose to occupy the small guesthouse on their property, later drawing on local craftsmen to expand it. I saw the interior of that house only once. Early one evening in 1975 , I was driving from neighbor to neighbor, asking if anyone had seen the missing twelve-year-old daughter of another summer resident. I found Ralph and Fanny in the main room with a beautifully set dinner table, including candles, obviously waiting for guests. They expressed concern and agreed to stay on the alert. Soon after I returned home, we learned that the girl was safe - it was all a misunderstanding. I telephoned to let the Ellisons know. Since this is the only time I recall seeing Fanny Ellison, she stays in my mind as a conscientious hostess, slightly nervous before the arrival of guests.

When one of Robert Frost's Amherst neighbors tried to describe his encounters with the poet, he could recall only occasions when he had caught Frost working in his yard. These brief incidents usually ended with Frost excusing himself to go into his house. Such distancing was not my experience with my neighbor Ralph Ellison. Our properties adjoined, though we could not see each other's houses through the thick woods along the hillside. He could get to the village center by two routes. The one that passed our house meant a steep drive into the valley followed by an equally steep, curvy ascent. At certain times, in certain moods, he chose that route with its dirt road, close-in foliage, and widely separated houses. If when he drove by, either Walter or I was in the yard, he would pause for a greeting, sometimes a chat. On occasion, he stopped his engine and stepped out of his car.

Neither of us ever referred to my letter of commiseration or the encounter at Amherst College. I doubt if he remembered them. But from the first, our exchanges were warm and neighborly. In an early conversation, trying to show that I knew something of his biography, I commented that we both came from Oklahoma. On several later occasions, Ralph mentioned this coincidence as if it were a special bond. Nothing was made of the fact that we had lived on opposite sides of Oklahoma's line of segregation.

Whenever we saw Ralph drive by in the early morning, we were pretty sure he was on his way to the store in Cummington, where a New York Times was held for him. Occasionally he'd ask if he should pick up a copy for us. Once he said resignedly, as if referring to a sentiment we would share, "Of course, there's lots about it we don't like, but we can't live without it."

Although he knew that I taught at Amherst College, that fact almost never entered our conversations. On one occasion, however, he asked me to suggest why he had received an unexpected and unexplained batch of documents from my colleague Leo Marx. As best I can recall, I conjectured that the documents probably dealt with the college's latest venture into interdisciplinary teaching, 
or, specifically, a course linking thermodynamics as understood by scientists and Henry Adams's version in his Education. Ralph seemed satisfied, indicating that presumably no reply was called for.

I also gathered that he thought of me as a fellow academic when he voiced his complaint that New York University, facing financial difficulties, had pressed him to do more teaching. The chair he held there, the Albert Schweitzer Professorship in the Humanities, was one of several established by the state of New York. It was up to each recipient institution to define the incumbent's duties, and the ones assigned to Ralph had originally been closer to those of a visiting writer.

Another of our casual chats, typical of the era, dealt with real estate values. The Ellisons had had a chance to buy a building in the then run-down Chelsea section of New York. They consulted their attorney, who assured them that there was little promise in the notorious neighborhood and that it was likely to decay further. Instead of trusting their instinct, the Ellisons accepted this advice and made their New York home in an upscale neighborhood bordering Harlem. Values in Chelsea skyrocketed, and Ralph told me of their regret at this missed opportunity.

Ralph expressed interest in seeing the interior of our three-level barn, built in the 1880 s. After tidying it up a bit, I arranged to show him through. When we entered the cluttered paint room, I said I hadn't intended to include that area. He smiled and commented, "A novelist would have known." I can recall only one other time that included any allusion to his status as an author. Having noticed an advertisement by Ralph's publisher indicating that his new novel would appear on the fall list, I told him how happy I was to learn this. He laughed and said not to take it seriously. It was simply a publisher's attempt to pressure an author.

Plainfield's postmaster, Jeanna Carver (no such category as a postmistress, she informed us) was a bright, outgoing person, eager to take leadership in the town. She displayed particular concern for Ralph Ellison. Even before he and Fanny had moved in, she made some copies of Invisible Man available for purchase in the post office, in those days a friendly, not by-the-book place. He often cited her in conversations with me as his source of local information and support. When visitors expressed interest in meeting this celebrated author, Jeanna usually put them off with the comment that he valued his privacy. This was our policy also. We assumed this must be true of a writer, though in our case, we had always found him friendly and unhurried.

Jeanna later shared a recollection that put Ralph in a new light for me. At the end of a social evening at the Seelyes' summer home, as he left the gathering, he slipped up behind her where she sat on the porch and kissed her, commenting, "I'll bet you've never been kissed by a black man before." Her account intrigued me. Racial identity was never mentioned when Ralph and I talked.

One encounter did occur, however, when race-consciousness surfaced. Ralph drove a large automobile, impressive less for its color (which in fact I cannot recall) than for always looking freshly washed and polished. It was unlike any other in Plainfield and conspicuous on our narrow roads. One day, he approached the 
house from a side road not part of his usual route. "But," I said, when he slowed and rolled down his window, "I knew it was you by your Cadillac." He seemed a trifle defensive in his answer: "It's not a Cadillac. It's a Lincoln Continental." His neighborliness continued unchanged, but I pondered this self-revelation for a long time. In those days, Americans were growing increasingly aware of the role of racism in our culture. Until then, it had seemed that our friendly relationship was above the issue. After all, we had in common our choice of an obscure New England hill town, our taste in newspapers, and our college teaching. But in this case, I was forced to realize that deep in my subconscious, racial stereotypes remained and could touch our pleasant association. In the days that followed, I could observe no change in Ralph's open friendliness. No doubt he had long been aware of this painful truth about his fellow Americans.

A rare period of tension developed when a longtime resident told the Ellisons that their land extended all the way down to River Road, along which our property lay. When Ralph mentioned the claim to me, I objected unkindly that the source was "a very old man." Some time thereafter, our cars met on an extremely narrow local road, and a word of greeting seemed called for. I said I hoped they had worked out their boundary, and Ralph responded, "I really don't know. My wife takes care of all that sort of thing." The matter died away. Presumably they realized that extensive though their property was, their land did not extend to River Road.

Later, the Ellisons spent less and less time in Plainfield, perhaps because of their purchase of a place in Key West. The last exchange either Walter or I had with Ralph was a telephone call during one of his now rare visits to Plainfield. He said he was calling to apologize for letting his lawn go unmowed. It was easy for Walter to reassure him. Like others in town, we had little reason to navigate the challenging steepness of Lincoln Street.

Influenced at the time by Erving Goffman's The Presentation of Self in Everyday Life, I asked myself, in this incident and other exchanges, what persona Ralph was presenting. The best answer I could come up with was the image of an unpretentious, middle-class, friendly neighbor. Turning the question back on us, I concluded that for our part, Walter and I tried to show that without being overawed, we recognized his achievement and high reputation, and also that we were too sophisticated to have racist attitudes. Not that I attributed conscious role-playing to either side.

A call from a Springfield reporter at the time of Ralph's death in 1994 revived some of these memories, and more recently the interest expressed by Horace Porter, a specialist in African-American literature, led to this re-examination. I conclude now that even our minor acquaintance with Ralph Ellison and the self he seemed to present are worth sharing. 


\section{Hugh Hawkins}

\section{Notes}

For support, suggestions, and corrections, I thank Nancy Allen, Jan Dizard, Allen Guttmann, Annie Morse, Susan Morse, Horace Porter, and Robert Romer

1. Jeanna Carver, from conversation with the author in the $1980 \mathrm{~s}$, and again at a panel before the Plainfield Historical Society in the 1990s. The only change in the two accounts was the calcification in the second that the incident followed a dinner party. 